\title{
PERAN ORANG TUA SEBAGAI HOMESCHOOLER DALAM PROSES PEMBELAJARAN ANAK DI RUMAH SELAMA MASA PANDEMI COVID-19
}

\author{
Nita Sunarya Herawati \\ STAI Darul Kamal NW Kembang Kerang \\ Email: sunarya.nsh@gmail.com
}

\begin{abstract}
Abstrak :
Orang Tua merupakan pendidik utama dan pertama bagi anak-anak mereka, karena dari merekalah anak-anak menerima pendidikan dari sejak mereka lahir hingga dewasa. Oleh karena itu bentuk pertama dari terdapat dalam keluarga. Orang tua memegang peranan yang penting dan amat berpengaruh atas pendidikan anak-anaknya. Semenjak diterapkannya kebijakan belajar dari rumah di masa pandemi covid-19, orang tua memiliki tanggung jawab serta kontrol penuh terhadap proses pembelajaran anak-anak mereka saat belajar di rumah. Oleh karena itu, orang tua dituntut sebagai homeschooler dalam rangka untuk memaksimalkan proses pembelajaran anak dirumah dengan menjadikan rumah sebagai ruang belajar yang nyaman dan kondusif.
\end{abstract}

Kata Kunci: orang tua, homeschooling, pembelajaran, Ppndemi covid-19

\section{PENDAHULUAN}

Peran orang tua terhadap anak dapat dijelaskan sebagai kewajiban orang tua kepada anak, memenuhi hak dan kebutuhan anak, mengasuh dan mendidik anak-anak mereka baik lahir maupun batin sampai anak tersebut dewasa, termasuk tanggung jawab dalam pendidikan anak

Selama masa pandemi covid 19, dalam rangka mencegah penyebaran virus corona, pemerintah telah menetapkan kebijakan bekerja,belajar dan beribadah dari rumah. Sehingga hampir semua instansi atau lembaga dan tempat ibadah untuk sementara ditutup, termasuk lembaga pendidikan. Adanya kebijakan tersebut tentunya menuntut guru dan peserta didik melakukan proses pembelajaran dari rumah via daring. Sehingga belajar dari rumah ini sangat membutuhkan keterlibatan orang tua dalam menemani, membimbing dan mengontrol proses pembelajaran anak (peserta didik). Oleh karena itu orang tua harus memahami bahwa peran mereka sangat penting dalam membimbing dan mengontrol anak selama proses belajar di rumah. Sehingga orangtua di tuntut menjadi “homeschooler" bagi anak-anak mereka dengan menjadikan rumah sebagai tempat belajar yang nyaman. 
Homeschooling (HS) adalah model alternatif belajar selain di sekolah. Istilah homeschooling juga biasa disebut "home education", atau "home-based learning" (pembelajaran berbasis dirumah) diamana orang tua berperan sebagai penanggung jawab utama (homeschooler).

Pelaksana Tugas Direktur Jendral PAUD dan Dikdasmen Kemendikbud, Harris Iskandar, mengatakan dalam proses pembelajaran di rumah, seharusnya guru dan orang tua diharapkan dapat mewujudkan pendidikan yang bermakna, tidak hanya berfokus pada capaian akademik atau kognitif. ${ }^{3}$

Menurut Mujiono "Belajar merupakan kegiatan yang kompleks, hasil belajar berupa kapabilitas. Setelah belajar memiliki keterampilan, pengetahuan, sikap, dan nilai. Timbulnya kapabilitas tersebut adalah dari stimulus yang berasal dari lingkungan, dan proses kongnitip yang dilakuakan oleh pelajar"4

Oleh karenanya orang tua harus memahami bahwa mereka bertanggung jawab dan memiliki peran penting untuk terlibat dalam proses penyelenggaraan pendidikan yakni mulai dari penentuan arah dan tujuan dari pendidikan, nilai yang ingin di capai, kurikulum pembelajaran hinngga cara belajar keseharian anak. Terutama dimasa pandemi saat ini dimana orang tua memiliki tanggungjawab penuh dalam mengotrol pembelajaran anak di rumah.

\section{PEMBAHASAN}

Virus Corona atau severe acute respiratory syndrome coronavirus 2 (SARS$\mathrm{CoV}-2$ ) adalah virus yang menyerang sistem pernapasan. Penyakit karena infeksi virus ini disebut COVID-19. Virus Corona bisa menyebabkan gangguan ringan pada sistem pernapasan, infeksi paru-paru yang berat, hingga kematian ${ }^{5}$. Dalam rangka mencegah penyebaran virus corona pemerintah telah menetapkan kebijakan bekerja,belajar dan beribadah dari rumah, sehingga secara nasional hampir semua instansi atau lembaga dan tempat ibadah untuk sementara ditutup, termasuk lembaga pendidikan. Adanya kebijakan tersebut tentunya menuntut guru dan peserta didik melakukan proses pembelajaran dari rumah via daring. Sehingga belajar dari rumah ini sangat membutuhkan keterlibatan orang tua dalam menemani, membimbing dan mengontrol proses pembelajaran anak (peserta didik).

Menurut Ngalim Purwanto orang tua adalah pendidik sejati, pendidik karna kodratnya. Oleh karena itu kasih sayang orang tua terhadap anak-anak hendaklah kasih sayang yang sejati pula, yang berarti pendidik atau orang tua mengutamakan kepentingan dan kebutuhan anak-anak, dengan mengesampingkan keinginan dan

\footnotetext{
3 edukasi kompas.com, 2020

${ }^{4}$ Mujiono, belajar dan pembelajaran. PT Rineke Cipta, Jakarta, 2006, h.10

${ }^{5}$ Alodokter.com
} 
kesenangan sendiri. Orang tua berkewajiban memelihara dan memberikan dan membesarkan anak, melindungi dan menjamin kesehatan baik jasmani dan rohani, termasuk menumbuhksn motivasi belajar anak..Dengan adanya motivasi dari orang tua, semangat anak dalam belajar tentu lebih baik dan lebih bersemangat. Oleh karena itu orang tua memiliki andil yang sangat besar terhadap keberhasilan pembelajaran di rumah maupun sekolah ${ }^{6}$.

Tanggung jawab orang tua terhadap anaknya dalam hal pengasuhan, pemeliharaan dan pendidikan anak, ajaran Islam menggariskannya sebagai berikut: 1). Tanggung jawab pendidikan dan pembinaan akidah 2). Tanggung jawab pendidikan dan pembinaan akhlak 3). Tanggung jawab pemeliharaan kesehatan anak 4). Tanggung jawab pendidikan dan pembinaan intelektual ${ }^{7}$.

Istilah peranan yaitu bagian atau tugas yang memegang kekuasaan utama yang harus dilaksanakan. Peranan memiliki arti sebagai fungsi maupun kedudukan (status). Peranan dapat dikatakan sebagai perilaku atau lembaga yang mempunyai arti penting sebagai struktur sosial, yang, dalam hal ini lebih mengacu pada penyesuaian daripada suatu proses yang terjadi. Peranan dapat diartikan pula sebagai sesuatu yang menjadi bagian atau yang memegang pimpinan terutama dalam terjadinya sesuatu hal. Ada juga yang merumuskan lain, bahwa peranan berarti bagian yang dimainkan, tugas kewajiban pekerjaan. Selanjutnya bahwa peran berarti bagian yang harus dilakukan di dalam suatu kegiatan.

Berdasarkan pemaparan di atas, yang di maksud dengan peranan orang tua menurut penulis adalah suatu fungsi atau bagian dari tugas utama yang dipegang oleh orang tua untuk dilaksanakan dalam mendidik anaknya. Peranan disini lebih menitikberatkan pada bimbingan, keikutsertaan atau keterlibatan orang tua terhadap anaknya dalam proses belajar.

Wraag memberikan pengertian tentang belajar, pertama, belajar merupakan suatu aktivitas yang disadari atau disengaja, sehingga direncanakan oleh pembelajar itu sendiri. Individu melakukan aktivitas baik secara jasmaniah maupun mental sehingga terjadi perubahan dalam diri individu. Kedua,belajar ialah interaksi antara individu dengan lingkungan (baik berupa manusia maupun objek-objek yang memungkinkan individu memeroleh pengetahuan dan pengalaman). Ketiga, perubahan tingkah laku merupakan hasil dari belajar. Keempat, perubahan hasil belajar ditandai pula dengan terjadinya perubahan kemampuan berpikir ${ }^{8}$.

\footnotetext{
${ }^{6}$ Porwanto, Ilmu Pendidikan Teoritis dan Praktis, PT Remaja Rosdakarya, 2009 Bandung, h. 80

${ }^{7}$ Ibid, h. 137-138

${ }^{8}$ Wraag, Effective Teaching. Routledge Publisher. London. 1994, h. 93
} 
Rebber memberikan dua definsi tentang belajar, yaitu: pertama, belajar merupakan sebuah proses memeroleh pengetahuan dan kedua, belajarmerupakan perubahan kemampuan individu yang bereaksi relatif langgeng sebagai sebuah hasil dari latihan yang diperkuat terus menerus ${ }^{9}$. Chaplin (1981: 45) memberikan definisi belajar, yakni: belajar merupakan pemerolehan perubahan tingkah laku dalam jangka yang relatif tetap sebagai dampak dari praktik dan pengalaman dan belajar merupakan sebuah proses mendapatkan respon sebagai akibat dari pelatihan khusus ${ }^{10}$. Selanjutnya Biggs (1985: 191) menyebutkan bahwa dalam bentuk apa pun pengalaman hidup sehari-hari sangat memungkinkan dimaknai sebagai belajar (everyday learning) ${ }^{11}$.

Berdasarkan pendapat ahli di atas, dapat disimpulkan bahwa belajar adalah sebuah proses aktivitas yang direncakan secara sengaja dan sadar sehingga berdampak pada terjadinya perubahan pola pikir dan tingkah laku individu, dari yang tidak tahu menjadi tahu dan tidak mampu menjadi mampu yang diperoleh dari praktik dan pengalaman nyata terhadap lingkungan. Perubahan perilaku sebagai dampak dari kegiatan belajar apabila bersifat positif. Pembelajaran dapat dimaknai sebagai sebuah proses dalam kegiatan belajar mengajar yang menempatkan peserta didik sebagai objek, sehingga memberi kesempatan kepada peserta didik untuk mengembangkan kemampuan yang dimiliki berdasarkan tujuan yang telah ditetapkan.

Teori belajar merupakan seperangkat pernyataan secara umum yang dimanfaatkan guna memberikan penjelasan kenyataan tentang belajar. Manfaat teori belajar bagi pendidik, yaitu: (1) membantu pendidik dalam memahami cara belajar peserta didik; (2) membimbing pendidik untuk merencanakan dan merancang proses pembelajaran; (3) memandu guru dalam pengelolaan kelas; (4) membantu pendidik guna melakukan evaluasi proses pembelajaran, perilaku pendidik, dan hasil belajar yang telah dicapai peserta didik; (5) membantu keberlangsungan proses belajar sehingga lebih efektif, produktif, dan efisien; dan (6) membantu pendidik untuk memberi bantuan dan dukungan kepada peserta didik sehingga mencapai prestasi yang maksimal ${ }^{12}$.

Teori-teori dalam belajar diuraikan sebagai berikut :

Teori Belajar Behavioristik: Soesilo menyebutkan bahwa aliran psikologi behavioristik memandang bahwa belajar tidak harus melibatkan emosi, minat, dan

\footnotetext{
${ }^{9}$ Reber, AS. (1988). The Penguin Dictionary of Psychology. Ringwood Victoria. Penguin Books Australia Ltd. Hal 54

${ }^{10}$ Chaplin, J. P. (1981). Dictionary of Psychology. New York: Dell Publishing Co. Hal. 45

${ }^{11}$ Biggs, J. B. (1985). The Role of Metalearning Study Process. British Journal of Educational Psychology.hal.191

${ }^{12}$ Sugihartono, dkk. (2013). Pskilogi Pendidikan. Yogyakarta: UNY Press.hal.89
} 
perasaan individu. Peristiwa belajar sebagai proses melatih refleks-refleks dengan adanya stimulus-respon membentuk kebiasaan yang dikuasi oleh individu. Artinya, proses belajar lebih menekankan pada tingkah laku individu sebagai akibat dari interaksi adanya stimulus dan respon. Terbentuknya perilaku individu merupakan sebuah hasil dari proses belajar ${ }^{13}$.plikasi dari teori ini, pendidik menyusun materi pembelajaran yang harus dikuasai oleh peserta didik dan disampaikan secara utuh oleh pendidik. Pendidik memberikan instruksi singkat (tidak banyak ceramah) dan diikuti dengan contoh-contoh melalui tindakan sendiri maupun simulasi. Materi ajar disusun secara hierarki (mulai dari sederhana sampai kompleks) dan tujuan pembelajaran berorientasi pada hasil yang bisa diamati dan diukur. Pembelajaran pada teori ini berpusat pada pendidik (teacher centered learning), di mana komunikasi berlangsung searah dan pendidik menentukan hal-hal yang harus dikerjakan dan dipelajari oleh peserta didik. Pengulangan dan latihan diberikan sebagai konsekuensi dari kesalahan yang dilakukan oleh peserta didik. Teori behavioristik memberikan tujuan akhir dari proses belajar ialah sebuah perilaku yang diinginkan, sehingga perilaku yang diinginkan cenderung mendapat penguatan positif dan perilaku yang tidak diinginkan memeroleh penghargaan negatif. Evaluasi/penilaian dilakukan berdasarkan perilaku peserta didik yang muncul setelah belajar ${ }^{14}$.

Teori Belajar Kognitif: Teori kognitif merupakan sebuah kritisi atas kelompok behavioristik, yaitu menekankan bahwa otak menjadi pusat dari pengendalian perilaku setiap individu ${ }^{15}$. Teoritisi kognitif menitikberatkan pada penjelasantentang motivasi, persepsi, dan pemecahan masalah yang terjadi pada masing-masing individu pada saat tertentu ${ }^{16}$.

Teori belajar kognitif berpendapat bahwa pengetahuan tidak semata-mata dapat dipindahkan dari pikiran pendidik pada pikiran peserta didik. Artinya, teori kognitif dapat diaplikasikan pada pembelajaran yang menempatkan peserta didik untuk aktif secara mental dalam membangun struktur pengetahuan berdasarkan tahapan kematangan kogitif. Teori kognitif memiliki konsep terkait bagaimana sebuah pengetahuan dapat diperoleh ataupun dibentuk, sehingga belajar adalah proses aktif dari peserta didik dalam membangun pengetahuan. Proses aktif tersebut meliputi aktif secara mental dan fisik. Artinya, aplikasi teori kognitif dilakukan dengan melibatkan

\footnotetext{
${ }^{13}$ Soesilo, T. D. (2015). Teori dan Pendekatan Belajar: Implikasinya dalam Pembelajaran. Yogyakart: Ombak.hal.22

${ }^{14}$ Sugihartono, dkk. (2013). Pskilogi Pendidikan. Yogyakarta: UNY Press.hal.103

${ }^{15}$ Ibid.hal.28

${ }^{16}$ Hill, W. F. (1990). Learning: A Survey of Psychological Interpretations. Harper Collins publisher.hal.156
} 
peserta didik pada kativitas secara fisik melalui proses asimilasi pengalaman atau bahan ajar dengan skemata yang dimiliki peserta didik dan hal ini berlangsung secara mental.

Teori Belajar Humanistik : Setiap individu dalam teori belajar humanistik dapat bebas menentukan, memilih, dan malakukan perilaku belajar berdasarkan minat dan keinginan individu ${ }^{17}$. Tujuan belajar dari teori humanistik ialah memanusiakan manusia. Keberhasilan proses belajar ditandai dengan adanya peserta didik yang mampu memahami diri sendiri dan lingkungannya. Teori ini berusaha memahami sebuah perilaku belajar tidak berdasarkan sudut pandang pengamat, melainkan sudut pandang pelaku belajar tersebut. menjelaskan tentang aplikasi teori humanistik lebih menitikberatkan pada spirit atau ruh selama proses pembelajaran berlangsung dan diwarnai dengan metode-metode yang diterapkan. Tujuan pembelajaran dalam teori humanistik menekankan pada proses belajar dibanding hasil belajar ${ }^{18}$.

Teori Belajar Konstruktivis: Kontruktivis merupakan sebuah filsafat belajar yang dibangun berdasarkan anggapan bahwa refleski pengalaman yang dilakukan oleh peserta didik menghasilkan sebuah konstruksi pemahaman diri peserta didik terhadap dunia $^{19}$. Selanjutnya Belajar menurut teori konstruktivis ialah proses aktif peserta didik di dalam mengkonstruksi pengetahuan ${ }^{20}$. Faktor penting yang memengaruhi belajar peserta didik adalah apa saja yang diketahui dan dialami secara nyata. Penerapan teori konstruktivis dalam belajar yaitu: (1) pendidik mendorong kemandirian dan inisatif di dalam belajar sehingga peserta didik merumuskan pertanyan-pertanyaan, menganalisis, dan menemukan jawaban; (2) pendidik mengajukan pertanyaan terbuka dan memberikan kesempatan kepada peserta didik untuk merespon pertanyaan sehingga peserta didikmmdapat melakukan penyelidikan; (3) mendorong peserta didik untuk berpikir kritis melalui prediksi, analisis, justifikasi, serta mempertahankan ideide pemikirannya; (4) peserta didik terlibat aktif dalam diskusi dengan orang lain; (5) pendidik memberikan data mebtah, materi interaktif, dan sumber utama sehingga peserta ddik dapat menganilis fenomen dalam dunia nyata ${ }^{21}$.

Berdasarkan uraian di atas dapat disimpulkan bahwa proses belajar merupakan upaya membantu anak untuk mengeksplorasi luasnya dunia dengan metode-metode dan tujuan pembelajaran, dimana peserta didik terlibat aktif dalam belajar, mengembangkan emosionalnya, dan menemukan pembelajaran yang bermakna bagi dirinya. Dalam hal ini yang menjadi pendidik dalam proses belajar di rumah adalah orangtua dan yang menjadi peserta didiknya adalah anak. Melalui belajar anak dapat

\footnotetext{
${ }^{17}$ Soesilo, T. D. (2015). Teori dan Pendekatan Belajar: Implikasinya dalam Pembelajaran. Yogyakart: Ombak.hal.35

${ }^{18}$ Sugihartono, dkk. (2013). Pskilogi Pendidikan. Yogyakarta: UNY Press.hal.116
} 
melakukan percobaan dengan memanfaatkan alam sebagai media terbesar. Keberhasilan anak dalam proses pembelajaran ditentukan oleh kemampuan belajar dari peserta didik. p\Proses belajar dipengaruhi oleh beberapa faktor, yaitu: konsep diri, motivasi, minat, sikap, dan kebiasaan belajar ${ }^{22}$

Adanya kesadaran akan tanggung jawab mendidik dan membina anak secara kontinyu perlu dikembangkan kepada setiap orang tua sehingga pendidikan yang dilakukan tidak lagi berdasarkan kebiassaan yang dilihat dari orang tua, tetapi telah disadari oleh teori-teori pendidikan modern, sesuai dengan kondisi yang cenderung selalu berubah. Seperti halnya ketika pandemi covid 19 saat ini, dimana orang tua dituntut untuk turut andil dalam pendidikan anak dan memiliki tanggung jawab penuh terhadap proses pembelajaran di rumah. Oleh karena itu orang tua harus memahami bahwa peran mereka sangat penting dalam membimbing dan mengontrol anak selama proses belajar di rumah. Sehingga orangtua di tuntut menjadi "homeschooler" bagi anak-anak mereka dengan menjadikan rumah sebagai tempat belajar yang nyaman.

"homeschooling is an alternatif form of education in which children are instructed at home rather than at a traditional public or private school. Children who are homeschooled are instructed by parents, guardians, or other tutors". Bahwa homeschooling merupakan pendidikan alternatif yang dilakukan di rumah (daripada di sekolah tradisional maupun sekolah privat) di mana anak mendapatkan pembelajaran baik dari orang tua, wali, maupun tutor ${ }^{23}$. Prinsip dalam pendidikan homeschooling yaitu sebuah keluarga bertanggung jawab sendiri atas pendidikan anak-anak dengan memanfaatkan rumah sebagi basis pendidikan. Orang tua terlibat langsung dan bertanggung jawab dalam proses penyelenggaraan pendidikan. ${ }^{24}$ (Sumardiono, 2007: $57)^{19}$

Orang tua yang memberikan perhatian ketika anak-anak beraktivitas dan terjaga dalam homeschooling, menjadi cara belajar yang efektif, sehingga anak-anak dapat belajar melalui pengalaman-pengalaman menyengangkan dari aktivitas yang dilakukan dengan berbagai kondisi, situasi, dan lingkungan yang semakin berkembang ${ }^{25}$.

${ }^{24}$ Sumardiono. (2007). Homeschooling A leap for better learning: Lompatan Cara Belajar. Jakarta: Kelompok Gramedia.hal.27

${ }^{25}$ Mulyadi, S. (2007). Homeschooling Keluarga Kak Seto: Mudah, Murah, Meriah, dan Direstui Pemerintah. Bandung: Kaifa

Herwina, W. (2016). Penerapan Homeschooling Sebagai Model Pendidikan

Alternatif Bagi Masyarakat Pedesaan. Prosiding Seminar Nasional: Homeschooling Versus Sekolah Formal Dialog Tentang Mutu Pendidikan yang Bermartabat. Universitas Negeri Semarang: Fakultas Ilmu Pendidikan Jurusan Pendidikan Luar Sekolah.hal.34 
Herwina mengungkapkan homeschooling merupakan pendidikan tentang hak asasi manusia, pendidikan yang berkualitas, harkat, dan keberpautan. Lingkungan homeschooling terkondisi di mana anak merasa disambut,dan dididik tanpa dibedabedakan, baik dalam latar belakang intelektual, fisik, jenis kelamin, emosional, sosial, linguistic,maupun karakteristik ${ }^{26}$.

Berdasarkan uraian pendapat ahli di atas, disimpulkan bahwa homeschooling merupakan model pendidikan yang mengedepankan otonomi anak untuk mempelajari hal-hal yang ingin dipelajari dengan bantuan dari orang tua, tutor, maupun wali, bertujuan mencapai masa depan anak yanglebih baik, dan media untuk menggapai tujuan pendidikan, sama halnya dengan pendidikan pada sekolah. Dalam praktik homeschooling, orang tua sepenuhnya menyadari peran dan tugasnya dalam memberikan pendidikan dalam tataran keluarga serta memberikan kesempatan kepada anak untuk mengaktualisasikan diri. Praktik pendidikan homeschooling sebagai pendidikan di luar sistem persekolahan dapat diselenggarakan di mana saja dan kapan saja, sehingga anak memperoleh sendiri pengalaman dari kegiatan belajarnya. Seperti halnya saat ini orang tua dituntut untuk menjadi pendidik, pembimbing, pendamping sekaligus sebagai wadah belajar anak di rumah. Dalam hal ini orang tua dapat mengacu pada kurikulum sekolah (formal) tempat anak mendapatkan pendidikan formal nya sebelum masa pandemi, atau bisa juga membuat kurikulum sendiri yang disesuaikan dengan tujuan-tujuan pendidikan nasional.

\section{Metode Penelitian}

Kajian ini merupakan penelitian kualitatif (qualitative research) yang bertujuan untuk menggambarkan dan menganalisis fenomena-fenomena, peristiwa, aktivitas sosial, sikap, kepercayaan, persepsi, pemikiran orang secara individu ataupun kelompok. $^{20}$ Penelitian ini terdapat upaya untuk mendeskripsikan, mencatat, menganalisis dan menginterpretasikan kondisi-kondisi yang saat ini terjadi. ${ }^{21}$ Penelitian ini hanya akan mendeskripsikan fenomena yang ada secara mendalam apa adanya, maka penelitian ini adalah penelitian deskriptif (descriptive research). Jenis penelitian deskriptif ini disebut juga penelitian praeksperimen karena dalam penelitian ini mereka melakukan eksplorasi dan menggambarkan fenomena dengan tujuan untuk dapat menerangkan dan memprediksi terhadap sesuatu yang berlaku atas dasar data

\footnotetext{
${ }^{20}$ Nana Syaodih Sukmadinata, Metode Penelitian Pendidikan, (Bandung: PT Remaja Rosdakarya, 2006), hal. 60

${ }^{21}$ Sanapiyah Faisal, Metodologi Penelitian Pendidikan, (Surabaya: Usaha Nasional, 1982), hal.
} 
yang diperoleh di lapangan. ${ }^{22}$ Selain itu penelitian ini dilakukan dengan tujuan mengembangkan pengetahuan yang mendalam mengenai objek yang diteliti, sehingga sifat dari penelitian ini lebih banyak bersifat eksploratif dan deskriptif. ${ }^{23}$

Selain itu dalam penelitian ini juga terjadi proses pengamatan dan pemaknaan atas fenomena yang terjadi di lapangan. Oleh sebab itu, pengumpulan data dalam penelitian ini dilakukan melalui tiga cara yaitu pengamatan (observation) untuk memahami sikap/tindakan yang terjadi, dan dokumentasi yang bisa berupa tulisan, gambar, rekaman, dan lain sebagainya.

Analisis data adalah rangkaian kegiatan penelaahan, pengelompokan, sistematisasi, penafsiran dan verifikasi data agar sebuah fenomena memiliki nilai sosial, akademis, dan ilmiah. ${ }^{24}$ Analisis data untuk penelitian kualitatif dimulai sudah sejak di lapangan. ${ }^{25}$

Melihat penelitian kualitatif yang menggunakan logika induktif, maka konseptualisasi, kategorisasi, dan deskripsi dikembangkan oleh peneliti berdasarkan kejadian, peristiwa, dan fenomena yang ada di lapangan. Karena itu, antara proses pengumpulan data dan analisis data dalam penelitian ini menjadi satu kegiatan yang integral dan sekaligus simultan. Peneliti akan mengikuti model Miles dan Huberman dalam melakukan analisis data. Data-data yang dianalisis melalui beberapa tahapantahapan, sebagaimana yang dikemukakan Miles dan Huberman (1984) bahwa aktivitas dalam analisa data, yaitu data collection, data reduction, data display, dan conclusion drawing/verification. ${ }^{26}$

\section{PENUTUP}

Selama masa pandemi covid 19, dalam rangka mencegah penyebaran virus corona, pemerintah telah menetapkan kebijakan bekerja,belajar dan beribadah dari rumah. Sehingga hampir semua instansi atau lembaga dan tempat ibadah untuk sementara ditutup, termasuk lembaga pendidikan. Adanya kebijakan tersebut tentunya menuntut guru dan peserta didik melakukan proses pembelajaran dari rumah via daring. Sehingga belajar dari rumah ini sangat membutuhkan keterlibatan orang tua dalam menemani, membimbing dan mengontrol proses pembelajaran anak (peserta didik). Oleh karena itu orang tua harus memahami bahwa peran mereka sangat penting

\footnotetext{
${ }^{22}$ Sukardi, Metodologi Penelitian Pendidikan; Kompetensi dan Praktiknya. (Jakarta: Buni Aksara, 2003), hlm. 14

${ }^{23}$ Nurul Ulfatin, Metode Penelitian Kualitatif di Bidang Pendidikan: Teori dan Aplikasinya, (Malang: Bayumedia Publishing, 2013), hal. 48

${ }^{24}$ Imam Suprayogo dan Tobroni, Metodologi Penelitian Sosial-Agama, (Bandung: Remaja Rosdakarya, 2003), hlm. 191

${ }^{25}$ M. Djunaidi Ghony dan Fauzan Almanshur, Metodologi Penelitian Kualitatif; Edisi Revisi, (Jogjakarta: Arruz Media, 2012), hlm. 274

${ }^{26}$ Sugiono, Memahami Penelitian Kualitatif, (Bandung: Alfabeta, 2009), hlm. 91
} 
dalam membimbing dan mengontrol anak selama proses belajar di rumah. Sehingga orangtua di tuntut menjadi "homeschooler" bagi anak-anak mereka dengan menjadikan rumah sebagai tempat belajar yang nyaman.

\section{DAFTAR RUJUKAN}

Biggs, J. B. (1985). The Role of Metalearning Study Process. British Journal of Educational Psychology.55.185-212. DOI: https://doi.org/10.1111/j.20448279.1985.tb02625.x

Brooks, J. G. \& Brooks, M. G. (1993). In Search of Understanding: The Case forContructivist Classroom. Alexanderia, VA: Association for Supervision and Curriculum Development

Chaplin, J. P. (1981). Dictionary of Psychology. New York: Dell Publishing Co.

Dimyati dan Mudjiono. 2006. Belajar dan Pembelajaran. Jakarta: PT Rineke Cipta

Djaali. (2014). Psikologi Pendidikan. Jakarta: Bumi Aksara.

Faisal, Sanapiyah. 1982. Metodologi Penelitian Pendidikan. Surabaya: Usaha Nasional.

Herwina, W. (2016). Penerapan Homeschooling Sebagai Model Pendidikan Alternatif Bagi Masyarakat Pedesaan. Prosiding Seminar Nasional: Homeschooling Versus Sekolah Formal Dialog Tentang Mutu Pendidikan yang Bermartabat. Universitas Negeri Semarang: Fakultas Ilmu Pendidikan Jurusan Pendidikan Luar Sekolah

Hill, W. F. (1990). Learning: A Survey of Psychological Interpretations. Harper Collins publisher

Lips, D \& Feinberg, E. (2008). Homeschooling: A Growing in American Education. Mulyadi, S. (2007). Homeschooling Keluarga Kak Seto: Mudah, Murah, Meriah, dan Direstui Pemerintah. Bandung: Kaifa

Ormrod, J. E. \& McDevvit, T. M. (2002). Child Development and Education: $6^{\text {th }}$ Edition. Merril: Prentice Hall

Purwanto, Ngalim. (2006). Psikologi Pendidikan. Bandung: PT Remaja Rosdakarya

Reber, AS. (1988). The Penguin Dictionary of Psychology. Ringwood Victoria. Penguin Books Australia Ltd

Soesilo, T. D. (2015). Teori dan Pendekatan Belajar: Implikasinya dalam Pembelajaran. Yogyakart: Ombak

Sugihartono, dkk. (2013). Pskilogi Pendidikan. Yogyakarta: UNY Press.

Sugiono. 2009. Memahami Penelitian Kualitatif. Bandung: Alfabeta.

Sukardi. 2003. Metodologi Penelitian Pendidikan; Kompetensi dan Praktiknya. Jakarta: Bumi Aksara.

Sukmadinata, Nana Syaodih. 2006. Metode Penelitian Pendidikan. Bandung: PT Remaja Rosdakarya.

Suprayogo, Imam dan Tobroni. 2003. Metodologi Penelitian Sosial-Agama. Bandung: Remaja Rosdakarya. 
Jurnal At Tadbir STAI Darul Kamal NW Kembang kerang NTB

Volume 5 No 2 Tahun 2021

P-ISSN : 2580-3433

E-ISSN : 2715-7210

https://journal.staidk.ac.id/index.php/tadbir

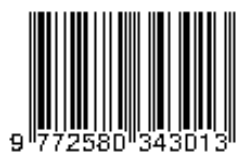

Sumardiono. (2007). Homeschooling A leap for better learning: Lompatan Cara Belajar. Jakarta: Kelompok Gramedia

Suparno, P. (1996). Filsafat Konstruktivisme dalam Pendidikan. Yogyakarta: Kanisius

Wragg, T \& Dunne, R. (1994). Effective Teaching. London: Routledge Publisher 